\title{
瞳孔光反射計測の新方法と曈孔光條件反射に於ける 刺戟時間關係
}

\author{
關西學院大學心理學研究室
}

美演 久 春**

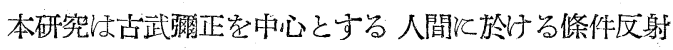
研究の一部で安る。而して本篇は睡孔光反射の條件形成 に閵する研究の第 3 報告である。

\section{I 緒 論}

瞳孔光反射の條件形成の研究は二つの方向をるつてい る。一つ橦孔光反射の條件形成の過程或は實驗條件自 體を條件反射原理の理解の立場から明らか、浓せんとする 方向である。これと關しては過去に人間及び動物と就い て 可成多くの報告 1)335)6(7)8)9910)(5)(9)24)25)26)28)29)30) があ り，又既古武・美濱もとの基礎的な實驗結果について 報告13)をなした。他の一つの方向はすすぐれた特性をるつ 瞳孔反射の生理的機能を條件反射研究に用了る事兘 て更々他の或吕種の心理生理的問題に何等かの理解が得 られるか否かといら事である。例えば Hudgins の瞳孔 條件反射の有意的支配の研究 ${ }^{10)}$ 等はこれで岕る。この方

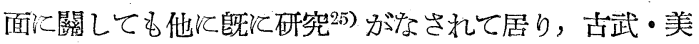
演もとれら基礎として追試的實驗少ら人間の堽孔條件 反射に於方言語的支配化て報告14)をなした。しかし 以上の結果に於て 典型的な無意的運動反射で劣る瞳孔光 反射の條件形成を容易々確立せしめる事自體が 未だに困 難であり，現在迄に至る多くの實驗結果がその決定的な 實驗手續及び條件を見出していない點々 Hilgardの指摘 した如く，7，p. ${ }^{683)}$ 條件反射の理論的な面认就ても又そ の生理學的な基礎沉於ても興味岁る問題で岁り, 同時飞 實驗の方法上飞種々の問題を含んで居る。

過去の研究報告及び實驗實施の經驗よりの見解を總覽 して二つの面について今後の問題がある。一つは條件刺

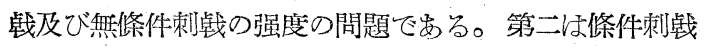

* A New Method for Measurement of the Pupillary Light Reflex and the Temporal Relation of Stimuli in Conditioning Pupillary Light Reflex.

(本研究は古武彌正を研究擔虽者をする。昭和27年度 交部省科學酷究費の補助に上るものである)

** By Mihama, Hisaharu. (Department of Psychology, Kwansei Gakuin University.)
と無條件刺戲の組合せの時間的闗係の問題て岁る。所 謂 backward conditioning は別考慮するとして，條 件刺戱及び無條件剌戱の組合せ方つ時間的關係基いて 同時，繼時，延滞，痕跡の條件反射形成の場合吕出來る が，更に夫々について子種々の長さの刺钱提示時間の組

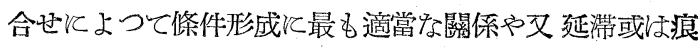
跡の條件形成の可能な時間的限界が見出されると考えら れる。，同時條件刺战及び無條件刺戲が岕る一定の時間 關係於て組合されて强化手續が 續けられる場合飞條件 反射つ現けれる時間的な位置が强化過程の經過と從つて 遷移するといら事實から反應の興舊と制止の複綜した力 動的な過程が見られるならば條件形成過程の分析に興味 ある問題である。

本研究はこの第二の點 郎ち瞳孔光反射の條件形成飞於 ける時間的要因に關するもので要す。從來の研究於い ては瞳孔反射の量的測定は 主と切線瞳孔計が使用せられ た。その操作々可成熟練を要する事, 又精密な連續的記 錄には限界がある事は多くの實驗者により認められて居 る。又從來少數ではるが寫貝撮影法によつて行はれた 測定でよ相當の照度を必要とする焉に 適當な實驗條件を 作る事は困䧼で゙すり，又赤外線寫自を用らればその缺點 はないとしてる可成脣い實驗過程の連續的記錄としては 實用には適していない。瞳孔條件反射研究の實驗條件と してで實驗操作による騒晋を伴ねずね且明確な潜時を現 はす瞳孔運動曲線として直接描寫が出來る事が 望まし い。本實驗に於ては從來に於ける方法を改新に光電管 そよる自記瞳孔計とより連續的且目働的に瞳孔變化を記 錄する方法を用いた。この裝置による測定方法は眼の調 節及び輻輳作用による堽孔反射えの影響や，眼球運動， 眼臉つ動き等による影響が介入せ好樣に 注意を拂うなら ば極めて正常な事態於ける瞳孔戀化を正確現々する のであると考えられる。現在の方法ては後汇述べる如く 反應量を直接拆 万には多少の問題はあるが獞孔光反射に

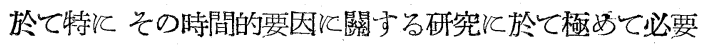
である反射潜時及び微細な虹彩の動き迄測定する事が可 能である事惵件反射研究の中て特渾動條件反射飞新 
しい分野を開くので泳いいと考えられる。

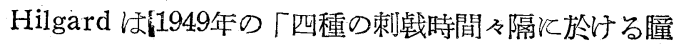

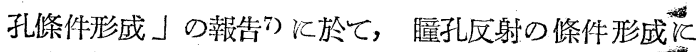

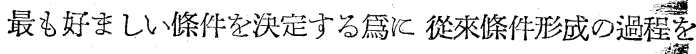
變容させる一つの要因之考えられている條件刺㦸と無條 件刺戱の提示の時間々融焉取上げ四つの間隔と就て試み た。この結果は何れの時間的關係に於ても條件反射の形 成が㱠ど不可能で岁るという否定的結果火 終つている。

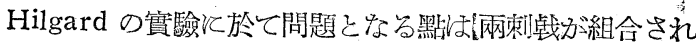
て提示されている時間，換言すれば無條件刺战が 3 秒で 岁つた事第一飞考慮すべきで安るかもしれない。第二

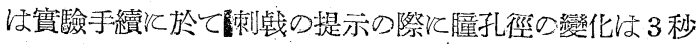
間隔每に測定せられその間の變化々测定されなかつた 點である。過去と於方る經驗と基くならばこの椂标機械 的な測定により得られた反應量の變化を 處理する方法に 對しては可成問題がある樣に考えられる。何故ならば瞳

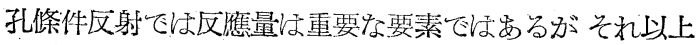
そ反應の潜時之その反應の形態认於河固有の安定性と 更飞系列中起る條件反射の頻度が意味をるつて居当と 考光ら机分からである。

双此處で問題となる事将制止の現象で岁る。瞳孔反射

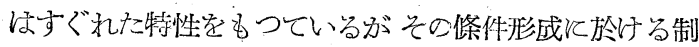
止の機制よ全く理解なられていない。制止によつて條件 形成過程中飞條件反射が随所飞抑制されたり，不安定性 を示したり時には無條件反射さえその反應速度の遲速に 變化が起り，從つて條件反射量の漸次的増加の過程の取

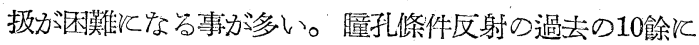
亘る研究結果に於てその可能性が相牛ばしているという 事實，又それらが互、忠筫なる追實踰の結果に於てその 樣な對立を示しているのば極めて僅かの實驗條件の相 違が制止の要因として働く結果ではないかと考えられ る。Pavlov の條件反射研究に於ては制止過程の現象と 理解江偉大な業績が示された。瞳孔條件形成の實驗過程 の中々も制止基く事筫が明らか反見られるとも拘らず 實驗條件或な眼の機能をる含めて被驗者の生理的乃至心 理的條件による制止過程法余りにも複雑であり，又條件

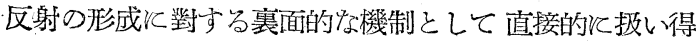
ない。之は筫驗の方法的努力以よつて制止が入らない樣 な條件を見出与か，或は種々の條件下於沙制止を伴 ろ可成多くの實驗結果の畒積を基礎として 制止過程の分 析的な理解がなされる事㣻望ましい。この點から Hil-

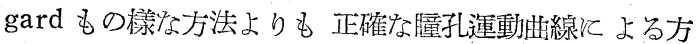

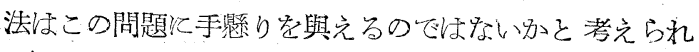
る。

本實驗は條件刺战と無條件刺战の七種の時間々隔の組
合せについて試み特にその中二種の條件に於ては夫ァ

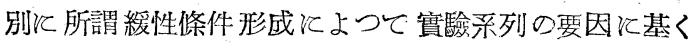
影響の比較を副次的問題として报つた。七種の中一つ は同時條件形成四つは 1 秒， 3 秒， 6 秒及び 9 秒の繼時 的な條件形成，二つは 0 秒及び 3 秒ひ痕踢條件形成てま る。瞨孔條件反射飞於ては條件形成の可能性自體の基礎 が確立されていない加ら，延滞痕跡の實驗的研究よりも むしろ，先ず條件形成の一つの重要な承數的要素として の時間的要因方澗題となる。郎去從來の筧液條件反射や G. S. R. の場合々異り，延滞の時間の長さ名ら延滞條 件反射の時間的限界を見出す事は未だ困蜼で岁る。從つ

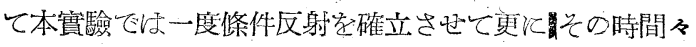
隔觉長く延滞させて行くといら方法学とらずと，初めか ら夫々特定の時間々隔の組反分けて形成せしめ“何れの 場合が最も條件として適當であるかという點，及び所與

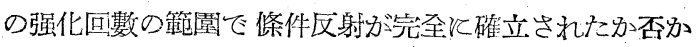
を夫々比較す当事よりも設定された時間關係の條件が 形成過程々於て如何なる反㷳の興奮 及び制止の力動的な 過程とその遷移の型を起させるかの二䁫々ついて考慮し た。

\section{II 實驗方法}

\section{〔實驗裝置〕}

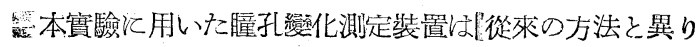
光電管自記朣孔計による眇孔徑連續措寫法にようた。こ れと原理的同じ方法ば瞳子運動の生理學的研究では 既 そ報告せられている18)。乙かしそれ等は瞳孔運動中光反 射や朣孔動摇等の 基礎的研究に用いられたものであり， 條件反射形成飞必要な條件として次の點学考慮した。第 一飞兩眼の凝視點を绫定する事飞より，眼の調節軦輳作 用の影響が入らぬ樣㲸する事。第二飞條件反射の强化過

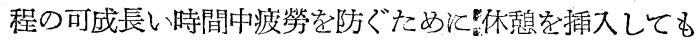
常に同じ實驗條件下に於ける瞳孔徑の變化が記錄されな ければならない。第三に被驗者を樂な姿樊に保たしめる と同時に 顏面及び眼球の運動や位置縝化を起させない 樣にする事等である。以上の如き諸鴜を考慮して第 1 圖 の如き裝置を用いた。主要な部分々受容裝置, 光電流增 幅裝置, 及び記錄裝置であり，附屬的々は切線瞳孔計， 凝視點，顏面固定裝置及び刺战提示裝置等である。

受容裝置法第 2 圖に略示した如く, $27 \times 20 \times 9 \mathrm{~cm}^{3}$ の顏 面を接着出來るフェルト張り彎为面のある中室鐵製の箱 で，中央に隔壁が岕り，瓦斯入光電管P G50(マツダ) を 中央の鼻の直前で兩眼の視線を遮げない位置と置く。出 彩照射筒は水本垂直に可動で方向と同時飞 調節螺旋によ

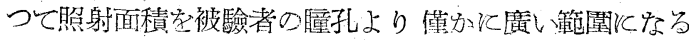


樣に合卞事が出來る。虹彩照射光は電流變化による影響 を防ぐためと專用の $6 \mathrm{~V}$ 湆電池を電源として用い，蛙彩 照射筒の中の $10 \mathrm{CP}$ の電球の光をレンズで收光し，スッ ット及びフィルターを通して睈孔、照射し，その反射光 を光電管に受ける樣沉す。フィルターは光電管の感度 特性を考慮して赤色 及び赤外線部の波長の光を通過せし めるものを用い，眼分ら光源迄の距離は $8 \mathrm{~cm}$ 視線 飞對して約 25 度の角度で水平外側から被驗者の无眼を 照射せしめる。光電管は锣孔より反射した光丈学受ける

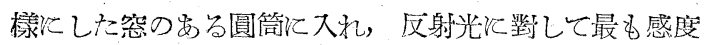

Fig 1 瞳孔徑測定裝置側面圖

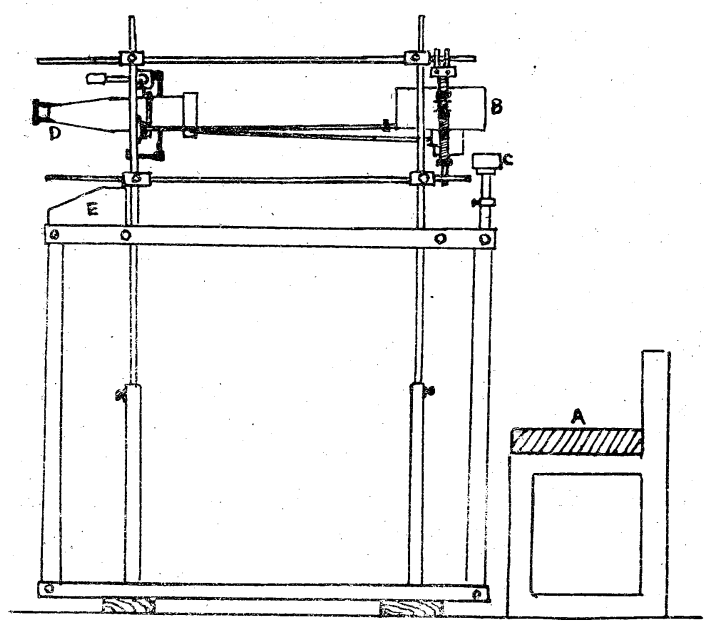
A 被驗 者
B 受容裝置
C 顔面固定囊

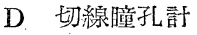
$\mathrm{E}$ 內側刺戟提示裝置

のよい位置化調節する。

瞳孔運動連續描寫の原理は一定の强さの虹彩照射光 で左眼の瞳孔及び周邊索照射しその反射光線を光電管 空〔゙受けとの際の虹彩運動 從つて瞳孔面積の變化によ

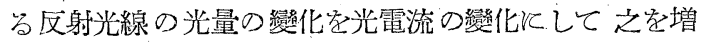
幅してインク書きオシログラフてミポリグラフ記錄紙汇 連續記錄するので岁る。眼底よりの反射光の變化は無視 乙得る程小さいから考慮外飞するとしてこの方法では 虹彩の色が濃調であつても淡調で岕つても睡孔と虹彩 との色の對比及び夫々そ對する照射面積の㓶合の變化に 基く反射光の變化を利用するもので，瞳孔收縮により反

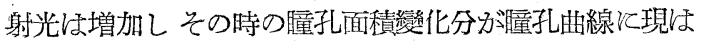
れることとなる。但しその際眼球運動及び調節輻軼作用 它防ぐため眼より $63 \mathrm{~cm} の$ 距離江直徑 $5 \mathrm{~mm}$ の圓型スリ

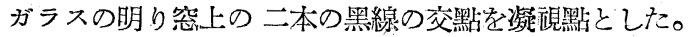
受容裝置中の光電管に外からの光が漏洩せ好樣汇眼の

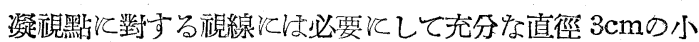
谷を二つ開けた。

受容裝置の隔壁の他側々は $6 \mathrm{~V}$ 滀電池觉電源とする 10C P の光源からスッット学通して被驗者の右眼と無條 件刺戲として刺㦸光学與光る。その右眼の照射汇よる左 眼の共感性反射を瞳孔運動曲線として 措寫する方法を用

Fig 2 受容裝置による瞕孔運動曲線 描寫の原理

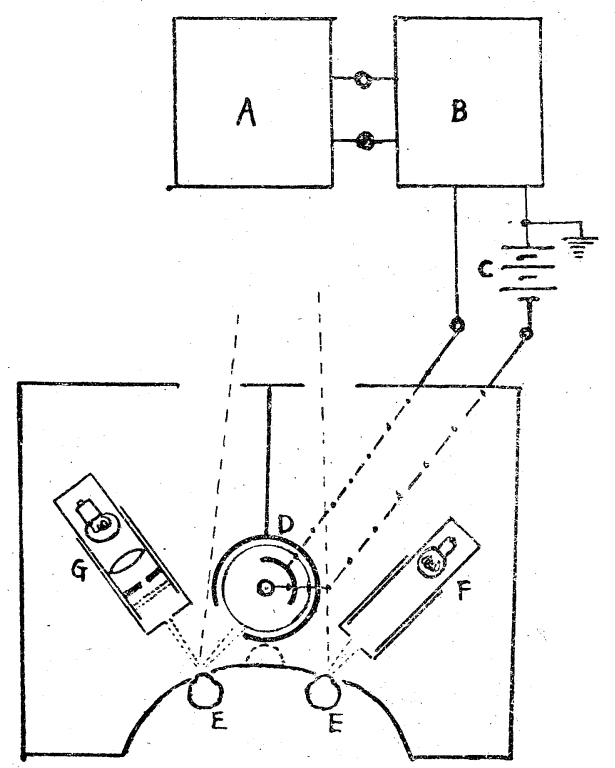
A 記錄裝置
B 直流增幅器
C $50 \mathrm{~V}$ 電源
D 圆筒中に收められを光電管
$\mathrm{E}$ 被驗者の眼
F 無條件刺戟光源
G 虹彩照射筒

Wた。この刺呼光も水平重直に照射方向が可動飞同時に 照射面積も調節吕出來, 光源は眼から $8 \mathrm{~cm}$ の距離て峴 線と對して 25 度の角度て水本外側より照射する。この刺 战光は隔壁の反對側の光電管に漏浑せ好樣に特飞注意し た。

光電流の増幅は差働型直接結合三段増幅器を用い, 増 幅された光電流をインク書オシログラフて條件刺战，無 條件刺战の提示時間及び秒刻と共飞記錄した。

その他附屬的裝置として以上の光電管による測定と 虽 行して瞳孔徑變化を量的と觀察するため切線堙孔計を 
併用し 主に對照實驗と用いたこ。

條件刺战は C-R 型發振器とよる1000サイクルの純音を 極限法により聽覺刺战の刺戱閾の强さで 兩耳用受話器で 與㝋た。

實驗は電氣的に充分遮蔽された㬏至で行い，實驗操作 は暗室の內外共に出來るが 對照實驗て切線獞孔計を併用 する以外は暞室外で刺戲提示及び記録を行つた。其他装 置及び回路の絕緣及び接地に充分注意し電氡的障碍を防 止した。

本實簽け主と時間的要因を問題としたてため゙記録された 瞳孔业線の結果はオシログラフの 針の措く固有の圓孤の 振れを考慮した。嚴密に考えるならば瞳孔曲線の動きは 直接疅孔の直徑或は面積の變化量を常に同じ尺度で忠實 と現はしているとは考えられない。何故ならば虹彩照射 光を瞳孔が光電管に向けて区射する場合，眼球の曲率や 虹彩の色の濃淡の個人羑, 照射光の範園內に於ける瞳孔 面積と虹彩面積の比率, 又光電管飞對する反射光の入り 方等で 反射光の光量は常に個人差があり, 同一個人でも 實驗の日時美が生ずるから 極めて微少な動き芝測定出來 るけれども記録された睡孔曲線から睡孔直徑乃至瞳孔面 積の數量的測定は团難で岁る。本研究は主に時間的關係 そ注目したが必要ならば切線朣孔計を併用し，又各個人 の大體一定した無條件反射量を條件反射量と相對的な割 合の比較て理解すると止める。

〔實驗手續】被驗者を實驗裝置の一側と樂な姿勢てて着席 せしめ受容裝置に顏面を接着し適當な位置に固定臺を 固定する。次で虹彩照射筒を調節して照射範瞏々眼瞼の 影響がなるべく入らぬ樣にし，同時に反對側の刺战光も 合せる。各實驗系列前に條件刺戱の强さを決める。實驗中 被驗者々頭部，眼球を固定して眼臉も大きく開いて受容

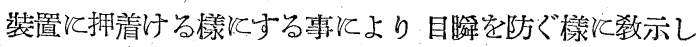
實驗時間は可成長くなるので開瞼器は使用しなかつた。

本裝置は從來行はれて瞳孔佟件形成の實驗條件と可成 異るため8名と就て用万べき刺戲々關する预備實驗を行

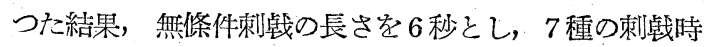
間々隔々ついて試久た。，豫備實驗於ては假性條件形成 とついてる對照實驗を行つた。7種の時間的闆係は次の 如くである。

實驗 I 條件刺战, 無條件刺戲 共に 6 秒で同時條件形 成による方法。

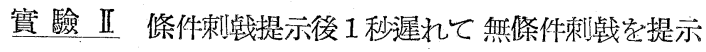

乙，兩刺戱を 6 秒間持續する。

實 驗 III 兩刺战の提示の延滞間隔は 3 秒で, 兩刺㼩共 6 秒間持續する。

實 羷 IV 兩刺䇳の提示間隔が 6 秒の場合。
實 驗 $\mathrm{V}$ 兩刺战の提示間隔が 9 秒の場合。

實 驗 VI 條件刺钱を 6 秒間提示しその終了と同時に 無 條件刺战を 6 秒間與光る。郎ち 0 秒の痕跡條件形成の 方法。

實 驗 VII 條件刺钱を 6 秒間提示し，その終了後 3 秒を 經て，無條件刺戱定 6 秒間提示与る。郎ち 3 秒の痕跡 條件形成の方法。

以上 7 つ條件による䗰驗に 何れも各被驗者について 夫々强化前江條件刺战及び無條件刺䟠の久就き數回宛 豫備的々瞳孔の動きを測定した後，1日20回の强化を行 い5 回强化每に 1 回の割合で條件剌戲丈学插入して測定 を行う。普通は連續して2 日計40回の强化を行い，その 後强化を伴にずに 數回速續測定を行万方法を用いた。强 化の各試行間には30秒乃至 2 分の間隔を祘き，その間は 被驗者は目由に休蒩せしめて眼の痏勞の影響が入らぬ樣 そした。

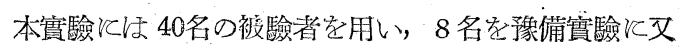
實驗 I より讬迄の各組については夫々 4 名宛用いた。。更

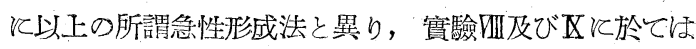

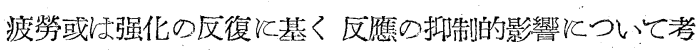
察するために 派生的と夫々 2 名の被驗者を用いて綏性條 件形成法を試み，實驗系列の條件差丈と基く要因の考察 そついて行つた。，即ち實驗训及び【は夫々實驗吕及びIV と實驗系列中の强化回數及び實驗日數の㷛を除いては 同 じ條件で行つた。何れも1日 6 回の强化と 1 回の測定を 插入し，7 日万至 10 日亘つて條件形成の過程を考察し た。

\section{III 筫 驗結果}

得られた結果な次の三點汇就て整理考察した。即ら第 一は瞳孔條件反射形成の難易々關する 刺战時間々隔の關 係，第二け各刺战時間關係による條件形成過程に於ける 條件反射の潜時, 及び第三は制止過程及びその起る際の 賽驗條件である。

實驗 I 刨ち同時條件形成江於ては條件反射は 本手續 による强化回數 40回以內では得られなかつた。4 例とも 插大测定時に於ては瞳孔動摇以上飞 條件反射少起る事よ 認められなかつた。

實驗 II 1 秒の繼時的な條件形成々於ては 4 例中 3 例 は否定的結果であり，他の 1 例も强化回數の増加と共に 條件刺钱飞對して瞳孔運動と絕えず不安定な動摇が認め られたが，一定の安定した型及び量をるつた反應は得ら れなかつた。

實驗II 師ち 3 秒の繼時條件形成飞於ても 4 例中 3 例 と就ては條件反射の事實は見られなかつた。3秒の刺钱 


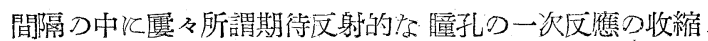
が認められ，乙かも强化過程の初期の間は 1 秒前後の比 較的早い時期《現われ 經過の進守沉て 2 乃至 3 秒

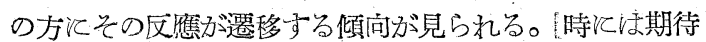

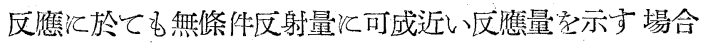
があるが，5回に 1 回つ割つ測定時水就て見ると認め得 る條件反射得られなかつた。唯他の 1 例火於ては可成 よい結果が得られた。特後飞述べる如く强化 過程の經過汇從つて興味焉学傾问がある。

實驗IVの 6 秒の刺战間隔と於ては· 4 例とも條 件区射流充分形成せられたととは言えない。，4例 中2 例次第1 日の强化 20 回中15回迄壮比較的漸

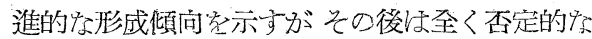
結果汇變つた。

實驗 $\mathrm{V} の 9$ 秒の間隔の手續では，何れも良好 な結果が得られた。その中1例を示すと第8圖 の如くで岁る。9 秒間の刺戱間隔《於ける期待 的反應の傾向は、强化回數の少小初期の䪸でな 體 2 秒前後の早い時期飞起り，强化過程の經過 そつれて 4 乃至 5 秒目飞移り，同時江條件刺战 の提示より 9 秒目頃郎ち無條件刺戱が與えられ て居た前後に收縮反射が認められる。勿論絶え ずその時間的位置に多少つ移動や反應量つ多㙞 が要劣，形成過程は明らかと條件形成が見ら れる。

賽驗 VI 郎ち 0 秒の痕跡條件形成法本實驗以 用いたこ手續き中條件形成が最も容易な時間的關係で岁る 事，示している。例を示すと第4 圖つ如くで岁る。特に 强化の經過伴亏條件刺战江對する瞳孔收縮反射が起る 時間的位置つ遷移は興味女る結果を示している。，郎ち强 化 5 回後の初期汇於ては條件刺戲つ提示丈現われた一 次的反應山動的な過程を示しつつ,やがて反應量を増し ながら安定した條件反射に近づく。しかもこの遷移の力 動的過程は 4 例中 3 例炕就て多少つ個人的差異はもると しても相互洋行的傾问が存在する。

實驗䜣の 3 秒の痕跡條件形成よ何孔も强化過程の最初 の 5 万至 10回の間飞比較的漸次的形成の傾向が認められ

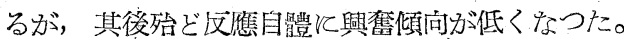

制止過程の現象飞ついて見ると實驗亚々於汗当可成 よい結果学示した1例及び實驗IVの强化 15回迄は比較的 漸進的な形成傾向子示した2 例，又筫驗䜣以於可强化 過程つ初期の傾问等飞於て一つの實驗系列が長い場合は 强化の加重の要因による制止が働くものそ考へられる。 實驗而飞於ける1例飞就て見るならば，第1日に於ては 强化回數が 20回中15回迄位條件形成の漸次的過程が見ら
れるが，15万至 20 回々於ては測定時つみならず强化時 飞子期待文碓飞抑制か㗢く。第2 日汇於て强化回數 8 回 位以後に反應は不規則な動摇㳙崩れ反應の抑制が現われ る。特にこの例に於ては第3日目にも同樣の實驗手續て 續けたが15回目迄は 明らか江條件形成が强められる傾向

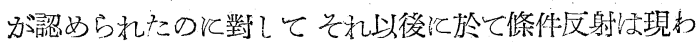
れなくなつた。今第1 日丈の結果とついて瞳孔運動圖を

Fig 3 筫驗 $\mathrm{V}$ 亿於ける1例

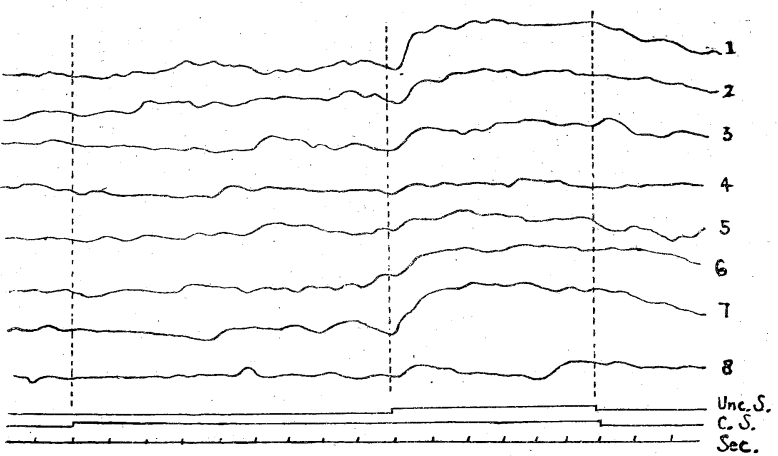

1 第1日强化第2回目

2 第 1 日强化第 8 回目

3 、第 1 日强化第 11 回目

4 第 1 日强化第 20 回目後の測定

5 第 2 日强化管 2 回目

6 第 2 日强化第 8 回目

7 第 2 日强化第12回目

8 第2 2 日强化第20回後の測定

Fig 4 賽驗VIに於ける1例

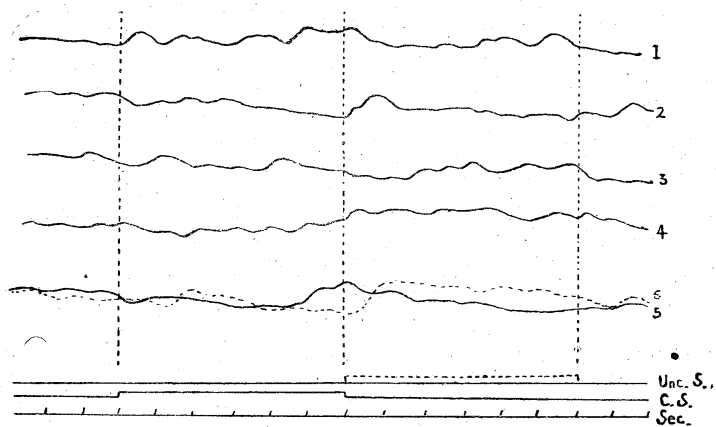

1 强化第 5 回後の測定

2 " 10 "

3 / 15 /

4 " 20 . "

5. 30 " 30

6 强化第30回目の瞳孔運動曲線 (條件反射量々無條件反射量比較の第) 
示すと第 5 圖の如くてせる。第 $\mathbf{5}$ 圖は第15回前後の强化 及び測定時と，制止をうけた第20回前後の瞳孔曲線の比 較を示している。

以上の諸例飞就ての結果から次の二點就て注目すべ き事實が認められる。第一は制止の機能が働いていると 思われる際は䑩條件反射である睡孔光反射の潜時がその 被驗者の固有の反射潜時より長くなる事。第二は無條件 刺戱の 6 秒間の提示が終つて瞳孔が散大と移る際 元の瞳 孔の直徑迄㞍る時間は普通は比較的速い、恢復を示すのに 對して條件反射が制止をうけて現われない前回の無條件 反射の散大恢復には可成長い時間を要する事が見られ る。 その時間的平均は可成個人差が大きく，又制止の程 度により異る。上述の如く第 5 圖の瞳孔運動曲線圖 1 及 び 3 の比較もその事實を示している。

Fig 5 賽驗而に於ける1例

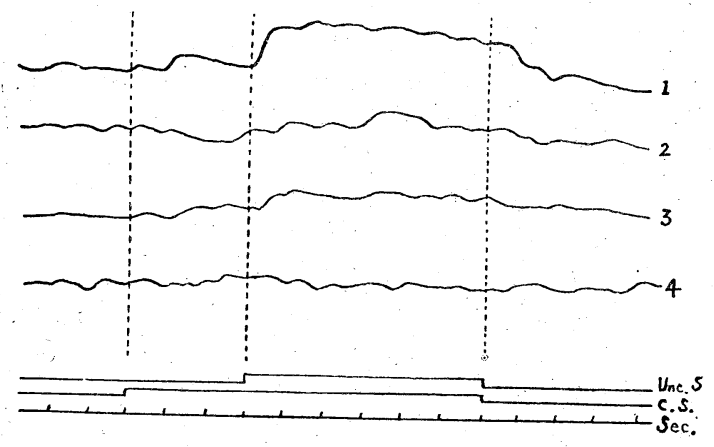

1 强化第15回目

2 强化第15回目後の測定

3 强化第20回目

4 . 强化第20回後の测定

本實驗に於ては手續に於て述べた如く附隨的と綏性形 成法を用いて此較した結果は實驗䜣及び区は何れも1日 の强化回數が少い爲に强化の强さは弱く第 5 乃至 7 日目

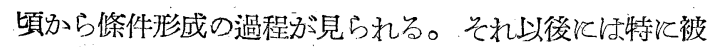
䛗者の眼の疲勞が甚だしい時以外に゙ 反應が抑制せられる 樣な傾向に見られない。

\section{IV 結果の考察及び結論}

現在に至る迄の多數の 睲孔光区射の條件形成《關する 研究の結果とその有する問題とを考慮して本實驗結果よ り次の諸笘を注目すべき默として述べる事が出來る。

1. 從來の實驗方法々異り光電管による連續的自記朣孔 運動描寫法により精密な時間的經過,並びそ瞳孔運動曲線 の測定が可能になつた。剖かし此處に得られた結果な隻 眼に對して常そ測定の雼の瞳孔照射光を與へ，他眼飞無
條件刺钱光を與へて，その共感性反射定測定する方法を 用いた瓷に從來の成功した實驗で用いられた適當な條件 飞於殀場合と直接比較々出來ない。無條件反射量と條 件反射量の相對的な量的比較を改めて今後に於て非常に 難、問題で昰るが 量的測定が直接出來る樣に改良する 事飞より條件反射の潜時, 頻度, 形態のみならず，そ の反應量の測定から，より充分な考察が出來る事が望ま LW。

凝視黑墨沉よる調節及び軴輳作用の影響や，光の照射條 件々よる無條件反射量, 又共感性反射を用いる事认は問 ・題となる點な存在しない。よりよき實驗條件は刺战の時 間的關係と條件刺战の强さの閣題で岁る。

2. 實驗方法に於て設定した9種の條件中無條件刺皒が 6 秒の際は睲孔條件形成に 最も適した時間間隔の關係は 9 秒の繼時的な條件形成及び 0 秒の痕跡條件形成法の場 合である。特に 0 秒及び 1 秒の繼時の條件で條件形成

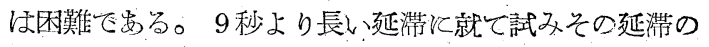
可能な限界及び最も條件形成に 好適な時間閣係を見出す 事は將來の問題として殘されて居る。痕跡條件反射で 條件刺钱及び無條件刺战の種々の長さの組合せ就て試 みる必要がある。上上の結果法何れ子40回の强化回數に 於け名條件形成の可能性の此較宗要り, 各條件飞於て條 件形成が可能力:否かは强化回數の増加との閵係江於て考 察しなければならない。

3. 本實驗の結果は總ての條件に於て瞳孔條件反射の確 立が容易に可能で岁るという結婨を下すをは充分でな い。明らか條件形成の過程汇制止機能の干渉による 反應の抑制の現象が起ると見るべきである。本實驗の條 件では大體强化回數 15回以後に於て制止過程が生ずると 考へられる。制止現象は無條件反射として起つた瞳孔收 縮が散大する際の恢復時間, 及び無條件区射である瞳孔 光反射の潜時汇關係がある。條件反射及び兩刺战の提示 間の延滞 或は痕跡間隔中に現われる所謂期待反應或よ 一次的反應の力動的な過程は興味女る問題であるが, 之は剌戱時間々隔や一日の實驗系列に於ける强化回數と その間隔等の爱因とついより好ましい條件が見出され たならばより充分な分析が可能で岁ると考えられる。

條件反射形成に於ける時間的要因々關する 理論的論議

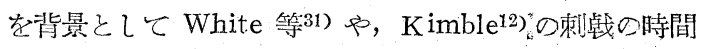
的間隔の實驗的研究は重要なものである。之等の結果は。 瞳孔條件区射於ても $1 / 2$ 秒附近の時間的條件てついて

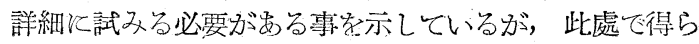
れた 0 秒や1秒と於けるよりる刺皒の延滞時間間隔が長 い方が條件形成が容易で省事はこの長い間隔が最も好 適な時間條件で岁る事を意味すると考へる以外に一種の 
政滞制止つ要因害も含妨て考慮する必要があると考へら れる。

從來に於て形成の可能性が問題にされ，又絕えず制止 現象によつて不安定な形成過程を示して居る 瞳孔條件反 射飞於て，その制止の機制理解が得られるならば從來 の問題觮決が與えられると思われる。本實驗で月らか そされて制止過程の際つ瞳孔運動の二つの特性と 更に收

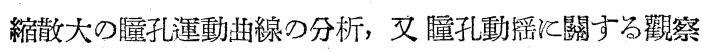
を進める事によつて Lowenstein 等16)17)の瞳孔運動曲線 からの瞳孔反射の神經支配の興奮 及び制止々關する基礎 的研究と共新しい展開が與えられるのではないかと考 へられる。

\section{交 献}

1) Baker, L.E. : The pupillary response conditioned to subliminal auditory stimuli. Psychol. Monogr., 1938, 50, No.223, 32pp. 2) Brown, R. H, \& Page, H. E. : Pupil dilation and dark adapt ation. J.exp. Psychol., 1939, 25, 347-360. 3) Cason, H. : The conditioned pupillary reaction. J. exp. Psycho'., 1922, 5, 108-146. 4) Ferree, C. E, Rand, G., \& Harris, E. T. : Intensity of light and area of illuminated field as interacting factors in size of pupil. J. exp. $P_{\text {sychol., 1933, 16, }}$ $408-422.5$ 5) Girden, E. : The dissociation of pupillary conditioned reflexes under erythroidine and curare. J. Exp. P:y.hol., 1942, 31, 322332. 6) Harlow, H.F., \& Stagner, R. : Effect of complete striate muscle paralysis upon the learning process. J.exp. Psychol., 1933, 16, 283294. 7) Hilgard, E. R., Dutton, C. E. \& Helmick, J S. : Attempted pupillary conditioning at four stimulus intervals. J. exp.Psychol., 1949, 39683 -689. 8) Hilgard, E. E., Miller, J, \& Ohlson, J. A. : Three attempts to secure pupillary condition. ing to auditory stimuli near the absolutethreshold. J.exp. Psychol, 194โ, 29, 89-103. 9) Hilgard, E. R. , \&Ohlson, J.A. : Pupillary conditioning to auditory stimuli near the absolute threshold. Psychol. Bull., 1939, 36, 577. 10) Hudgings, C.V.: Conditioning and the voluntary control of the pupillary light reflex. J.gen. Psychol., 1933, 8, 3-51. 11) Hudgins, C.V. : Steckle and Renshaw on the conditioned iridic reflex : a discussion. J.gen. Psychol., 1935, 12, 208 -214. 12) Kimble G. A. : Conitioning as a function of the time between conditioned and unconditioned stimuli. J. exp. Psychol., 1947, 37, 1 -15. 13）古武啢正・美濱久春：人間代於ける瞳 孔反射の條件形成・心理學研究, 1951，22，77-87. 14）古武彌正・美濱久春：C.V.Hudgins の方法に 上る瞳孔條件反射の有意統制・ 心理學研究, 1952, 23 88-92. 15) Kotoliarevsky, L. I. : The forma- tion of pupillary conditioned reflexes and of a differentiation in response to both direct and verbal stimuli. Ark. biol. Nauk., 1935, 39, 477-489. (Biol. Abstr ,1937, 11, No.13724) 16) Lowenstein, O , \& Lowenfeld, I. E. : Role of sympathetic and parasympathetic systems in reflex dilation of the pupil : Pupillographic studies. Arch. Neurol. Psychiat., 1950, 64, 313-340. 17) Lowenstein, O., \& Loewenfeld, I.E. : Mutual role of sympathetic and parasympathetic in shaping of the pupillary reflex to light: pupillographic studies. Arch. Neurol. Psychiat., 1950, 64, 341-375. 18) 眞柄钽正: 瞳孔運動火關する研究 (第一報). 新鼬醫 學會椎誌, 1948, 62, 10, 9pp. 19) Metzner, C,.A.\& Bker, L.E. : The pupillary response condition. ed to subliminal auditory stimuli: a control experiment. Psychol. Bull., 1939, 36,625. 20) $\mathrm{Pa}$ ge, H.E. : The relation between area of stimulation and intensity of light at various levels of visual excitation as measured by pupil constriction. J.exp.P.ychol., 1941, 29, 177-200 21) Reeves, P. : Rate of pupillary dilation and contraction. Psychol. Rev., 1918, 25, 330-340 22) Rodnick, E. H. : Characteristics of delayed and trace conditioned responses. J. ex r. Psychol., 1937, 20, $409-425$. 23) Rodnick, E. H. : Does the interval of delay of conditioned responses possess inhibitory properties? J.exp. Psychol., 1937, 20, 507-527. 24) Steckle, L.C. : Two additional attempts to condition the pupillary reflex. J. g n. Psychol., 1936, 15, 369-377. 25) Steckle, L. C. , \& Renshaw, S. : An investigation of the conditioned iridic reflex. J. g(n. Psychol., 1934, 11, 323. 26) Stern, F. : An investigation of pupillary conditioning. Unpublished $\mathrm{Ph}$. D. dissertation, Univ. Washington, 1948. (Psychol. Absir,,1949, 23, No.404.) 27) Switzer, S. A. : Anticipatory and inhibitory characteristics of delayed conditioned reactions. J. exp. Psychol, 1934, 17, 603-620. 28) Ten Cate, J. : Die Pupillenverengerung, als bedingter Reflex auf akustische Reize und ihre Beziehung: zu der Grosshirnrinde. Arch. néerl. Physiol., 1934.19, 417-425. 29) Watson, J. B. : The place of the conditioned reflex in psychology. Psycho', . Rev., 1916, 23,89-116. 30) Wedell, C. H., Taylor, F. V., \& Skolnick, A. : An attempt to condition the pupillary response. J. exp. Psychol., 1940, 27, 517-531. 31) White, C. T. \& Schlosberg,H. : Degree of conditioning of the GSR as a function of the period of delay. J. exp. Psychol., 1952, 43, 357-362. 32). Young, F. A., \& Biersdorf, W. R.: An apparatus for taking rapid photographs of the pupil in visual darkness. Amer. J. Psychol., 1952, 65, 617-618.

$$
\text { - 1953.7.18. 受稿 - }
$$

